when in the acute phase with intermittent catheterisation and when the acute phase ceases, after I 2 weeks, 83 per cent. have sterile urine. And now people leaving us, of about between 92 per cent. and 93 per cent have sterile urine, which is being described in a thesis by Jacob of our centre. We had to find a way of examining the sphincter system of the bladder and we didn't dare to put in a catheter because we knew it was going to infect the bladder, and so this induced us to do ciné-radiography and we think it is a good method.

\title{
HETEROTOPIC OSSIFICATION AND THE SURGICAL TREATMENT OF SERIOUS CONTRACTURES
}

\author{
By L. M. J. CouvéE, M.D. \\ Rehabilitation Centre 'De Hoogstraat', Leersum, Holland
}

THE first publication concerning heterotopic ossification, dating from 1918, originates from Déjerine and Ceillier (I9I8). They found 48.7 per cent. abnormal ossification in cases of paraplegia. This percentage probably includes different forms of pathological ossification apart from true heterotopic ossification. The classifications of heterotopic ossification as reported in the literature are:

Peri-articular bone-formation;

Para-osteo-arthropathia;

Neurogenic ossifying fibromyopathy;

Heterotopic ossification;

Osteosis neurotica (para-articularis) (para-ossalis);

Myositis ossificans circumscripta neurotica.

Writing about heterotopic ossification Damanski (I96I) not only deals with true heterotopic ossification, but he includes ossification in cases of decubitus and septic arthritis and accordingly reaches high percentages, while all the patients described suffered from decubitus. He records 162 cases of traumatic paraplegia and I03 cases of other affections of the spinal cord covering a period of twelve and a half years. There were 47 patients with pathological ossification in the group of traumatic paraplegia cases and 25 in the group of non-traumatic paraplegia cases. He noticed a decreasing percentage in the course of the years, which may be due to a better treatment of decubitus. Describing heterotopic ossification we should differentiate between various forms:

I. Septic arthritis, often resulting in widespread ossification including all weak tissues and following the course of local infection and necrosis, intra-articular as well (Hardy \& Dickson, I963).

2. In the case of decubitus ulcerations we often notice sclerotic bone without lamellae, Haversian systems or bone-marrow. This kind of bone formation is mainly found round the trochanters and tubera ossis ischii.

3. Myositis ossificans. This is a properly defined calcification and ossification, chiefly in muscle haematomas or injured tissue.

4. Peri-articular bone formation or true heterotopic ossification. This is found in the case of injury of the central nervous system, especially with frontal 
injuries, hemiplegia (Irving \& Le Brun, I954; Roberts, I968) and cerebral injuries caused by anoxaemia and hypercapnia. It is described in encephalitis, multiple sclerosis, tetanus (Gunn \& Young, 1959), anterior poliomyelitis (Costello \& Brown, I95I) and serious burns. Different percentages are recorded in cases of injury of the spinal cord, more in cases of total paraplegia than in partial ones and in cases of acute paraplegia, such as caused by a trauma, more than in those brought about by other causes. Wharton and Morgan (1970) found 90 patients with heterotopic ossifications in 447 cases of paraplegia. That is a percentage of 20; 27 per cent. in males and 9 per cent. in females. Twenty patients, or 3 per cent., had serious hindrance from joint fusion by heterotopic ossification.

Initial Phase. The onset of peri-articular ossification mostly dates from the sixth to the tenth week after the trauma and may be progressive up to one year hence. The first phase is either acute or gradual, imperceptible on the X-ray photograph in the beginning, not even when a solid osteoid mass is palpable. The clinical picture of an acute case may resemble that of thrombosis. In one case we found fever, redness, oedematous swelling, local rise in temperature and gradual restriction of mobility. The bone fraction of the alkalic phosphatase is sometimes found positive at this stage. The X-ray photograph clearly shows when the bone formation is mature by a difference between sclerotic and surrounding tissue and a trabecular pattern within. In most cases the picture shows little or no change for years. The original bone is mainly osteoporotic. Only a minority of cases results in serious restriction of the articular function or complete ankylosis.

Localisation. The affliction only occurs distal from the trauma, never distal from the knees, and most of all in the proximal joints of the extremities, i.e. hips and shoulders, knees and elbows. In the shoulders it is mostly noticed in the adductors, in the elbows, in the biceps but also in the triceps, in the hips mostly from the pelvis to the linea intertrochanterica in the course of the iliopsoas, sometimes in the gluteus medius and minimus region. Distally, the process often extends into the adductors, the bone often being more compact distally. In the knees the ossification is located mainly on the medial side; in some cases, however, on the lateral side or in the course of the quadriceps muscle and tendon. The ossification is found both extra-articular and extra-capsular.

Pathological Anatomy. The atrophic muscles are replaced by young fibrous tissue, surrounding the atrophic muscle tissue. The young fibrous connective tissue is transformed into osteoid tissue and the latter into lamellate bone, forming Haversian systems and bone-marrow. All stages of ossification from connective tissue into bone, containing bone-marrow and Haversian systems, may be demonstrated.

Etiology. Many factors have been considered liable to cause peri-articular ossification. Silver's view (I969), that trauma, such as vigorous passive exercise, promote peri-articular ossification seems plausible. Other causes of the spreading of ossification, according to Damanski, are continuous lying on the stomach, especially in a plaster-of-Paris bed, with pressure on the M. quadriceps and on blood-and-lymphatic vessels, as well as oedema and hypoproteinaemia. Periarticular ossification is also brought about, according to Damanski, by omitting passive and active exercise. According to Maury (unpublished paper). all cases 
with peri-articular bone formation have serious neurovegetative disorders in common. They might be the same neurovegetative disorders that often cause stomach and intestinal ulcers. The circulation, distally from the trauma, is supposed to be insufficient because of arterio-venous shunts. We might learn more about the circulation and especially the respiratory quotient of the tissues by studying the results of the peripheral arterial and venous blood for oxygen and carbonic saturation, acidity and alkaline-reserve, both proximally and distally from the trauma, and on the sides with and without peri-articular ossification respectively. Arteriographies might help to gain some insight into the circulation.

Prevention. Without knowledge about the cause, prevention is hardly possible. Important points in medical treatment seem to be: sufficient frequency in turning the patient, mobilisation as early as possible, correction of anaemia and hypoproteinaemia and avoidance of too vigorous passive therapeutic exercises.

Therapy. In our centre peri-articular ossification occurs regularly. Urological X-ray photographs often show peri-articular ossification in a small degree, although hardly any restriction of mobility in the joints is noted. There are a number of cases, however, in which peri-articular ossification has spread in such a degree and is located so unfavourably, that mobility is seriously restricted. That is why so far 2I operations were performed on I 2 patients by the orthopaedic surgeon attached to the rehabilitation centre 'De Hoogstraat'. The results of these operations can be seen in the table. Operation took place when the location of ossification was clearly defined. Most operations were performed more than one year after the onset of the affliction. There was occasional regression of the increased mobility achieved by the operation, but apart from one case, the results mentioned were lasting more than half a year up to more than one year later. In Io cases out of 12 , improvement has been attained to a greater or lesser extent. In a number of cases the patients were able to sit up once more; in other cases there was improvement in walking or independence was increased by greater flexibility of the elbow. Passive and, if possible, active therapeutic exercises were applied after the operation in order to retain the results achieved. These exercises are often painful. Occasionally the joint was bent after the operation under anaesthesia. The joints were sometimes put in splints for a time in order to retain the results achieved. To prevent infection we do not operate in cases of decubitus. Infections of the urinary tract should be cured. Some time before the operation the patient is transferred to a ward where no serious infections exist. Wharton and Morgan (1970) also advise strenuous manipulations to fragment the ossification, resulting in a useful range of motions.

\section{SUMMARY}

A report is given of heterotopic ossification and the results obtained in twelve patients are presented. They were operated upon because of serious limitation of mobility in one or more joints.

\section{RÉSUMÉ}

Ein Bericht über heterotopische Ossifikation wird gegeben und die Ergebnisse an I2 operierten Patienten beschrieben, die wegen schwerer artikulärer Bewegungsbehinderung operiert wurden. 
TABLE

Results of Surgical Treatment of Heterotopic Ossification

\begin{tabular}{|c|c|c|c|c|c|c|c|c|}
\hline Nr. & Sex & Age & Diagnosis & Date of onset & $\begin{array}{l}\text { Concerned } \\
\text { articulation }\end{array}$ & $\begin{array}{l}\text { Flexion/extension } \\
\text { before operation }\end{array}$ & Date of operation & $\begin{array}{l}\text { Flexion/extension } \\
\text { after operation }\end{array}$ \\
\hline I & $\mathrm{F}$ & $2 I$ & $\begin{array}{l}\text { Contusio cerebri spastic } \\
\text { quadriplegia }\end{array}$ & $3 \cdot 5 \cdot 1963$ & Right hip & $150 / 170$ & 6.1.1965 & $140 / 170$ \\
\hline 2 & $\mathbf{M}$ & 32 & $\begin{array}{l}\text { Incomplete traumatic } \\
\text { paraplegia } C_{5}\end{array}$ & 27.8.1964 & $\begin{array}{l}\text { Right hip } \\
\text { Left hip }\end{array}$ & $\begin{array}{l}150 / 170 \\
140 / 170\end{array}$ & $\begin{array}{l}\text { 20.4.1966 } \\
\text { 22.10.1966 }\end{array}$ & $\begin{array}{l}\text { 160/170 (infection) } \\
\text { 160/170 (infection) }\end{array}$ \\
\hline 3 & $\mathrm{~F}$ & 43 & $\begin{array}{l}\text { Traumatic paraplegia } \\
\text { Th. I2 }\end{array}$ & 14.7 .1965 & Left hip & $140 / 170$ & I2.10.1966 & $100 / 180$ \\
\hline 4 & $\mathbf{M}$ & 24 & Contusio cerebri & 23.10.1966 & Right elbow & $90 / 90$ & I2.7.1967 & $90 / 90$ \\
\hline 5 & M & I6 & $\begin{array}{l}\text { Incomplete traumatic } \\
\text { paraplegia } \mathrm{C}_{4}\end{array}$ & I9.II.1966 & $\begin{array}{l}\text { Left elbow } \\
\text { Right elbow } \\
\text { Left elbow }\end{array}$ & $\begin{array}{l}90 / 90 \\
120 / 120 \\
45 / 130\end{array}$ & $\begin{array}{l}\text { I9.7.1967 } \\
\text { 3.1.1968 } \\
\begin{array}{c}27 \cdot 3 \cdot 1968 \text { (2nd } \\
\text { operation) }\end{array}\end{array}$ & $\begin{array}{l}45 / 130 \text { (act. } 90 / 130) \\
60 / 130 \\
45 / 130 \text { (neurolysis } \\
\text { N. ulnaris) }\end{array}$ \\
\hline 6 & $\mathrm{M}$ & 23 & $\begin{array}{l}\text { Contusio cerebri hemi- } \\
\text { plegia right side }\end{array}$ & 26.6.1967 & Right hip & I55/1 55 & I7.9.1968 & $130 / 175$ \\
\hline 7 & $M$ & 25 & Contusio cerebri & 5.9.1967 & Right elbow & $130 / 130$ & 19.3 .1969 & $100 / 150$ \\
\hline 8 & $\mathrm{~F}$ & 26 & $\begin{array}{l}\text { Ependymona medullae } \\
\text { C7-Th. 5. Paraplegia } \\
\text { Th. } 7\end{array}$ & March 1968 & Left hip & $140 / 180$ & 21.5 .1969 & $90 / 180$ \\
\hline 9 & $\mathbf{M}$ & 43 & $\begin{array}{l}\text { Pneumococcal meningo- } \\
\text { encephalitis }\end{array}$ & Feb. 1968 & Left elbow & $90 / 90$ & 29.1.1969 & $65 / 130$ \\
\hline Io & $\mathbf{M}$ & I 8 & Contusio cerebri & 6.4.1968 & $\begin{array}{l}\text { Left elbow } \\
\text { Left hip } \\
\text { Right hip } \\
\text { Right knee } \\
\text { Left elbow }\end{array}$ & $\begin{array}{l}65 / 65 \\
145 / 145 \\
150 / 150 \\
160 / 170 \\
90 / 90\end{array}$ & $\begin{array}{l}\text { 22.1.1969 } \\
\text { 16.4.1969 } \\
\text { 11.6.1969 } \\
\text { 9.7.1969 } \\
\text { 1.10.1969 (2nd } \\
\quad \text { operation) }\end{array}$ & $\begin{array}{l}90 / 90 \\
60 / 170 \\
60 / 180 \\
60 / 180 \\
85 / 95\end{array}$ \\
\hline I I & $M$ & 47 & Central cord lesion $\mathrm{C}_{4}$ & $17 \cdot 4.1968$ & Left elbow & $85 / 95$ & 29.I.1969 & $65 / 115$ \\
\hline 12 & $\mathrm{M}$ & 35 & Contusio cerebri & 24.12.1968 & $\begin{array}{l}\text { Left elbow } \\
\text { Left elbow } \\
\text { Right elbow }\end{array}$ & $\begin{array}{l}180 / 180 \\
90 / 150 \\
140 / 150\end{array}$ & $\begin{array}{l}\text { 4.6.1969 } \\
\text { I.10.1969 (2nd op.) } \\
\text { 4.1.1970 }\end{array}$ & $\begin{array}{l}90 / 150 \\
45 / 140 \\
55 / 135(22.5 \cdot 1970)\end{array}$ \\
\hline
\end{tabular}




\section{ZUSAMMENFASSUNG}

Une communication est donnée, portant sur les ostéomes et le résultat opératoire sur I2 malades présentant des limitations importantes au niveau d'une ou plusieurs articulations.

Acknowledgment. I am obliged to my colleague J. H. J. van de Kamp, orthopaedic surgeon, for permitting me to publish the results of his operations and to Mr. N. Papadakis for his assistance in making slides of X-ray photographs and tables.

\section{REFERENCES}

Costello, F. V. \& Brown, A. (I95I). F. Bone and ft Surg., 33-B, 594.

Damanski, M. (I96I). F. Bone and $\mathcal{f}$ t Surg., 43-B, 286.

DÉJERINE, MME \& CeIllier (I9I8). Am. Med., 5, 497.

GunN, D. R. \& Young, W. B. (I959). F. Bone and ft. Surg., 4I-B, 535.

HARDY, A. G. \& Dickson, J. W. (I963). F. Bone and ft. Surg., 45-B, 76.

IRVING, J. \& Le BRUN, H. (I954). F. Bone and 7 t. Surg., 36-B, 440.

RoBERTS, P. H. (1968). F. Bone and $\mathcal{f}$ t. Surg., 50-B, 70.

SILVER, J. R. (1969). Paraplegia, 220.

Wharton, G. W. \& Morgan, T. H. (1970). F. Bone and ft. Surg., 52-A, I05.

\section{Discussion}

Dr. L. S. MichaELis (G.B.). It is inevitable that I should talk about this, because the problem of how to deal with ankylosis has given me many headaches and few joys. May I suggest to Dr. Couvée to carry on his research but that he should keep strictly apart those instances of ectopic ossification, which occur in connection with local infection. I know that Damanski in his paper a few years ago didn't separate ectopic ossification in the course of bony infection underneath pressure sores from the cryptogenic ossification which occurs in the absence of infection. I think we shall not be able to clear the ground before we treat these two kinds of ossification separately. May I also add to your information one cause of this mysterious condition which you have not mentioned and which has been described in France. That is ectopic ossification occurring in tetanus. Now I have time only to show you a few slides of two cases which I have chosen for a number of reasons. Firstly, both are late results of operation. No early results should ever be relied upon. The result in the first operation is 5 years old, in the second 4 years. Secondly they show different methods to deal with the condition which occurs in various ways. The anterior approach to the ossified mass is not always sufficient and so I had to devise a different method to deal with this particular type. Remember that these people were not operated upon before they were completely ankylosed, before their plasma-phosphatase had returned to normal. It sometimes rises as high as 60 and if you operate on these, already ankylosed, joints with a plasmaphosphatase like that, you can be absolutely certain that ossification will recur. Wait until the plasma-phosphatase has returned to normal and you will have a chance of getting away with it. The first slide is that of a 25 -year-old nurse treated by us within a fortnight of her accident in Northern Ireland. About I 8 months later she had already massive ossification which developed 6 months after injury. We waited, and it was at this stage that I removed a large part of the anterior masses. It is very important not to injure the femoral artery, which is hidden in this bone. I have seen this girl a few months ago but it wasn't her hips which made her return to us. She had good passive movement, $90^{\circ}$ flexion, and full extension, but a bilateral dislocation of the hip due to spasticity, which now, with the ankylosis removed, pushed the heads backwards. She also came to us with extensive pressure sores. So, by removing the ossifications we 
have exposed this patient to a new danger, which even this very intelligent girl, who was a nurse, couldn't prevent. Another patient shows the type of peri-articular ossification which, in contrast to the first slide I have shown, is not confined to the front of the joint. The hip joint is perfectly intact but ossification is surrounding it. Excision is not possible. You cannot go right round the femur and get rid of all the bone in a sufficiently short time to get the patient off the table alive. I had in this case to use a different method. I decided to do an intentional sub-trochanteric pseudoarthrosis. I sharpened the proximal end of the shaft of the femur into a kind of pencil and shaped the lower part of the extensive ossification into a semi-circular joint-surface. Then I put traction on that leg, carefully, with only a few pounds on the skin, which I removed every other day. That was four years ago. Shortly after the operation you see a big gap, and that there is rebuilding of bone, but this is not all in the same plane. The patient had good movement, could comfortably sit in a wheel chair; that was important since the patient was at work; and could comfortably lie in bed. His leg was perfectly straight. This picture is 4 years since the operation and you see how beautifully a new joint surface has formed on the proximal side and the opposite joint surface on the sharpened end of the femur. He has a wide joint-space. I have examined him clinically and he has quite free movement for over $90^{\circ}$ and, what is very interesting and important, no dangerous rotation of the lower limb. This, after all, could rotate to a degree when the femoral artery would be diagonally squeezed and there would be danger for the blood supply for this foot. This has not happened in this case, and I am happy to say this is a real success. These two cases I have shown confirm the justice of Dr. Couvée's remark that one should not operate in the presence of urinary infection.

\section{THE MODERN TREATMENT OF CONSTIPATION DIOCTYL FORTE THE ORIGINAL FAECAL SOFTENER}

Tablets of dioctyl sodium sulphosuccinate $100 \mathrm{mg}$. B.P.C. 1968

Classified: Category A.2.

Dose: 1-2 tablets t.d.s.

DIOCTYL FORTE produced "a statistically significant improvement without untoward side-effects".

The Practitioner, 200, 693 (May 1968)

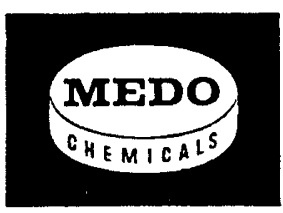

MEDO-CHEMICALS LTD.

144 Fortess Road

London, N.W.5

Telephone : 01-485 3352 